\title{
Reducing of Water Turbidity by Hydrotechnical Structures on the Example of the Wloclawek Reservoir
}

\author{
Dawid Aleksander Szatten ${ }^{1 *}$, Zygmunt Babinski', Michał Habel ${ }^{1}$ \\ 1 Department of Revitalization of Waterways, Faculty of Physical Education, Health and Tourism, Kazimierz \\ Wielki University in Bydgoszcz, Koscieleckich Square 8, 85-033 Bydgoszcz, Poland \\ * Corresponding author's e-mail: szatten@ukw.edu.pl
}

\begin{abstract}
The dynamics of river sediment transport reflects morphogenetic processes taking place in the catchment, being at the same time an anthropogenic indicator. The aim of the research is to determine the impact of hydrotechnical structures on the continuity of suspended sediments transport. The research area is the Lower Vistula River with a single dam - Wloclawek, operating since the 1970s. The research included direct measurements of water turbidity in 2013-2016 in characteristic cross-sections of the Vistula River, using commonly used methods. The LISST-25X laser grain composition measurement sensor was also used to collect data, enabling determination of grain size of the suspended sediments. However, on the selected section of the river, modelling of momentary transport of suspended sediments using GIS tools was carried out. There was a significant dynamics of sediments transport in the longitudinal profile of the river, in relation to the diversity of hydrological and morphological conditions of the Vistula River. The impact of Wloclawek Reservoir on water turbidity reduction was determined. The balance of transport of suspended material was related to the processes of erosion and sediment accumulation below the dam. The functioning of the Wloclawek Reservoir in the current system (as a single dam) has a significant impact on sediment transport, which directly determines the course of fluvial processes across the entire Lower Vistula (from $\mathrm{km} 675$ to the estuary) and indirectly in the coastal zone of the Baltic Sea.
\end{abstract}

Keywords: suspended sediments transport, turbidity of water, hydrotechnical structures, Wloclawek Reservoir.

\section{INTRODUCTION}

The challenge for sustainable water management is to provide water of good quality for people, agriculture and industry. One of the methods of water retention in the catchment area is the construction of artificial reservoirs. There are over 45000 large reservoirs worldwide (dam height of at least $15 \mathrm{~m}$ ), which serve flood control and water management [Nilsson et al., 2005]. However, their creation affects the functioning of the entire river system. Interference can be described as a balance of benefits (primarily from the economical point of view) and losses - determined in accordance with the provisions of the Framework Water Directive [2000/60/EC] as environmental pressures.

Rivers play a significant role in the global hydrological cycle, providing about 20 billion $t \cdot$ year ${ }^{-1}$ river's sediments to the world's ocean, reflecting climate changes occurring as a result of human activity [Syvitski, Kettner, 2011]. The creation of an artificial reservoir results in a change in the runoff of waters from the catchment area. They contribute to changing the natural hydrological regime of the river [Byczkowski, Żelazo, 1992] not only through the reservoir itself, but also through human water management - discharge regulations. This results in a change in the frequency of flood occurrence and their sizes. There is a decrease in maximum discharge during floods and an increase in extremely low discharges. It is estimated that about $40 \%$ of the river runoff on a global scale is stopped by artificial reservoirs [Vörösmarty et al., 2003].

Due to the fact that water is an energy carrier for the intensity of river sediments transport, the construction of dams also affects the continuity of 
its transport. Dams accumulate transported sediments, which results in a decrease in their operating capacity and storage [Kondolf et al., 2014]. In addition, in the case of large, individual dams, the impact of their functioning can reach the estuary. There are changes in the estuary areas of rivers that are characterized by a smaller supply of sediments [Vörösmarty et al., 2003], which results in changes in the delta areas [Syvitski et al., 2009; Habel, 2013].

The dynamics of sediment transport affects the hydromorphological state of the rivers, which is one of the partial assessments in determining the ecological status, in accordance with the requirements of the Water Framework Directive [2000/60/EC]. At the same time, it affects the transport of fine fractions of the dissolved sediments, including biogens, which below the dams have a significant role in the biological production process, determining the bioactivity of the water environment.

\section{METHODS}

The main aim of the research is to determine the impact of hydrotechnical structures on the continuity of suspended sediments transport, based on the example of the Wloclawek Reservoir.

Due to the way of transport, river sediments can be divided into three types: dissolved load, suspended load and bed-material load [Knighton, 1998]. As part of the research, the focus was on two components of the sediments transport: suspended and wash-load. A suspended sediment is one where the particles are transported without contact with the bottom of the river, but some of the transported material may fall off due to a reduction in the discharge of water in the river. In turn, wash-load sediments are particles moving in the mass of water that transports them. They consist of the smallest mineral and organic particles, kept in water by the component of the water discharge velocity vector. In this case, the transported material has occasional contact with the bottom and the material raised once from the bottom moves over considerable distances [Van Rijn, 1984].

The area of research on the dynamics of suspended sediments transport in the Lower Vistula is between Wloclawek ( $\mathrm{km} \mathrm{675)}$ and Grudziadz (km 835). However, selected studies took place on a wider section - from Warsaw ( $\mathrm{km} \mathrm{512)}$ to the Przegalina Lock (km 936).
The research included direct measurements of water turbidity in years 2013-2016 and analysis of available data for measurement profiles in the analyzed area. The sampling was carried out using a bathymeter according to the methodology used in the National Hydrometeorological Service [Brański, 1990], which is adequate to the commonly used methods [Wren et al., 2000]. The sampling took place in a representative place of the cross-sections of the river channel, in order to determine the load of the suspended sediments by filtration (in $\mathrm{mg} \cdot \mathrm{l}^{-1}$ ). Tests were made at the Laboratory of Water Quality Analyzes at the Kazimierz Wielki University in Bydgoszcz. Measurements of water turbidity were carried out using a turbidimeter (in FNU - Formazin Nephelometric Unit). Turbidimeters are easy to handle and most popular devices for suspended sediments monitoring [Felix et al, 2016]. In addition, on the selected cross-section (Torun), dispersed measurements of water turbidity were carried out in order to implement a momentary model of transport of suspended material in the section of the Vistula River. Modelling was carried out using the Geographic Information System tools - ArcMap v. 10.0. The study of grain size distribution of suspended material in water was carried out in 2014 at selected cross-sections in the longitudinal profile of the Vistula. For this purpose, the laser grain composition measurement sensor LISST-25X (Laser In Situ Scattering Transmissometer) was used, manufactured by Sequoia Scientific Inc. It is a device used to measure water turbidity in real time [Agrawal, Pottsmith, 2000]. The volumetric distribution of suspended load and particle grain size of silt was determined.

Studies on the dynamics of fluvial transport have been conducted so far on rivers and reservoirs, characterized by different catchment characteristics with different impacts of anthropopressure. The most important works on the impact of reservoirs (including Wloclawek Reservoir) on the dynamics of sediments transport can be included: Van Rijn [1984], Kondolf [1997], Łajczak [1999], Walling, Fang [2003], Vörösmarty et al. [2003], Shotbolt et al. [2005], Babiński [2002, 2005], Gierszewski [2007], Hu et al. [2009], Magnuszewski et al. [2010] oraz Habel et al. [2017].

\section{STUDY AREA}

The sediments transport in the section of Lower Vistula River has undergone significant 
transformations as a result of the commissioned of the Wloclawek Reservoir in 1970. The dam is located in $\mathrm{km} 675$ and the backwater reaches the town of Wykowo - km 618. At the length of about $57 \mathrm{~km}$ of the river's, 408 million $\mathrm{m}^{3}$ of water is stored at the normal damming level, of which only 55 million $\mathrm{m}^{3}$ is the usable capacity [Achrem, Gierszewski, 2007]. The surface of the reservoir is $75 \mathrm{~km}^{2}$. It is the largest artificial reservoir in terms of surface area in Poland [Rocznik..., 2016]. The Wloclawek Reservoir is a typical valley reservoir in which the reolimnic part (km 618-655) and limnic part (km 655-675) can be isolated. This division affects the dynamics of transport and sedimentation. The reservoir is a multi-purpose facility performing functions: energy, retention or shipping. The annual electricity production of the Wloclawek hydroelectric power plant is $740 \mathrm{GWh}$. It was the only one to be implemented from the cascading plans for the lower part of the Vistula River, which affects the course of fluvial processes throughout the entire lower section of the Vistula (up to the estuary). Currently, projects are being prepared for the construction of another dam and reservoir - Siarzewo. Its location is planned at $\mathrm{km} 709$.

According to E. Achrem and P. Gierszewski [2007], Lower Vistula River concentrates about $65 \%$ of the basin's water resources and about $30 \%$ of Poland's hydroelectric resources. The Wloclawek Reservoir has a significant share in this. Its regime is shaped mainly in the upper part of the basin. The Vistula River catchment area has a surface of $194424 \mathrm{~km}^{2}$, of which about $75 \%$ correspond to the lowland river. Mean annual flows on the Vistula trend to increase down the river. While in Skoczewo the river discharge amounts to $6.23 \mathrm{~m}^{3} \cdot \mathrm{s}^{-1}$, in Zawichost they reach $450 \mathrm{~m}^{3} \cdot \mathrm{s}^{-1}$, and $1090 \mathrm{~m}^{3} \cdot \mathrm{s}^{-1}$ in Tczew [Habel, 2013]. In addition, the regime is disrupted by intervention water discharges (repair regime) and to enable inland navigation (artificial flood wave) on the part of river below the dam [Habel, 2013].

In terms of hydrography, the area of the Lower Vistula includes a fragment of the river from the estuary of the Narew River to the Gdansk Bay. However, for the article, a fragment of the river from the Wloclawek Reservoir (km 675) was assumed to be the lower section of the Vistula River to the estuary to the Gdank Bay (km 941). The total area of so defined river basin is 39.5 thousand $\mathrm{km}^{2}$ [Mapa..., 2007]. The Vistula River, which is the subject of research, is the hydrographic axis of three physical-geographical georegions, separated by J. Kondracki [2002]. These include: Torun-Eberswalde ice-marginal Valley (315.3), Lower Vistula Valley (314.8) and the Gdansk Coast (313.5). In terms of administration, it is part of voivodships (according to the course of the river): Kuyavian-Pomeranian and Pomeranian (Figure 1).

\section{RESULTS AND DISCUSSION}

In most river systems around the world actually show decreased sediment loads, because of trapping by upstream dams [Walling, Fang, 2003]. This is not only an operational problem but also an ecological one. It affects the intensification of water eutrophication and possibilities of transport of the pollutants. The balance of the river sediment supply shows the spatial and temporal changes taking place in the river system, which are also reflected in the morphological transformations of the river channel [Turowski et al., 2010].

The continuity of transport of the suspended sediments of the Lower Vistula River was preserved until the beginning of the 20th century, when it was decided to conduct regulatory works. Another strong intervention of human was the construction of the dam in Wloclawek, which had a decisive influence on the dynamics of suspended material. The main sources of supply of suspended sediments from the Lower Vistula are: channel sediments from the eroded bottom material, material accumulated during the creation of a new floodplain - today due to destroyed regulatory buildings - eroded and material supplied with tributary waters. Also locally the growth of water turbidity is affected by the intake of sand and gravel from the bottom of the channel and water transport.

The impact of the Wloclawek Reservoir on the continuity of suspended sediments transport can be considered in various spatial aspects (presented in studies): from microscale - the influence of local hydrological and morphometric conditions of the channel on the transport of the suspended material to macro scale - in the longitudinal profile of the river (Middle - Lower Vistula).

\section{WLOCLAWEK RESERVOIR}

The average annual supply of clastic-load by the Vistula River to the Wloclawek Reservoir reached about 2.9 million ton, including 2.2 mil- 


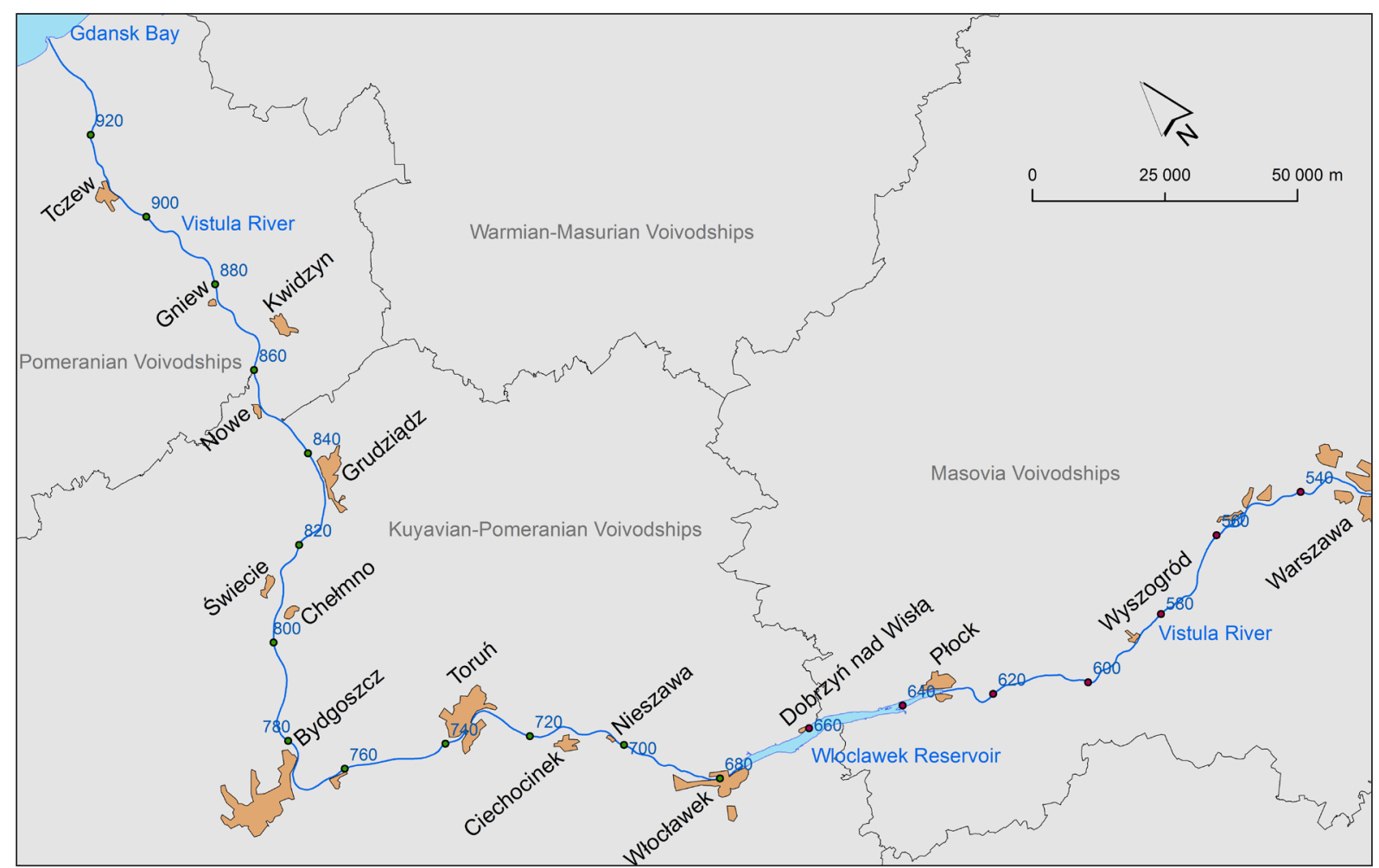

Figure 1. Study area of the Lower Vistula River [Mapa..., 2007].

lion ton of bedload and about 0.7 million ton of suspended sediments [Babiński, 2005]. The Wloclawek Reservoir accumulate $100 \%$ of the bedload material. It is accumulated mainly in the upper part of the reservoir. If the discharge increases, it is accumulated in further parts of it. Below the bedload accumulation zone, accumulation of suspended sediments occurs, which is estimated by various researchers from about 42\% [Babiński, 1992 ] to about 50\% [Gierszewski, 2007]. According to the first author, the average reduction of the suspended load in the period 1971-1995 for measurement stations located above (Kepa Polska) and below (Torun) of the Wloclawek Reservoir, amounted from $664000 t \cdot y e a r^{-1}$ to $346000 t \cdot y e a r^{-1}$.

The research indicates a decrease in concentration of the suspended sediments as the Vistula River course (Table 1), which confirms the thesis about the accumulation of sediments in the Wloclawek Reservoir. Occurrence of extremely high concentrations of the suspended load is characteristic for the lower part of the reservoir. Due to its limnic regime, it is characterized by a high value of the coefficient of variation (Table 1) illustrating the temporary supply of material from the coastal zone of the reservoir [Gierszewski et al., 2005]. However, high concentration may be also related to the resuspension of sediments accumulated in the front part of the reservoir at the moment of launching the intervention water discharge. The results may also reflect the high biological production of phytoplankton, which may be recorded in the results of water turbidity [Slaets et al., 2014].

\section{DISTRIBUTION OF SUSPENDED SEDIMENTS TRANSPORT IN LONGITUDAL PROFILE}

The turbidity of the Upper and Middle Vistula waters, examined in detail by A. Lajczak [1999], is determined by the morphogenetic conditions of the catchment basin. The size and frequency of floods, which are intensified by human activity, were considered the decisive factor in the process of denudation. This reflects the significantly higher level of turbidity recorded during the research over the Wloclawek Reservoir (Figure 2). The values of water turbidity oscillated between 18 and 54 FNU on this section (average for the part above the reservoir - 36.4 FNU). Then, in the area of the dam, there is a noticeable decrease in the value of turbidity, which indicates an increased accumulation of suspended sediments. Therefore, the dynamics of transport of suspended sediments on the part of Lower Vistula River is strongly related to the process of the erosion 
Table 1. Characteristics of the suspended sediments concentration (SSC) in the Wloclawek Reservoir in the years 1982-2002 according to the Voivodship Inspectorate of Environmental Protection - updated [Achrem, Gierszewski 2007]

\begin{tabular}{|l|c|c|c|c|}
\hline Measuring stations & $\mathrm{km}$ & Regime part & Average SSC [mg. -1] $^{-1}$ & Coefficient of variation [\%] \\
\hline Wyszogrod & 588 & river & 30.1 & 66.2 \\
\hline Plock & 632 & fluvial & 26.5 & 51.1 \\
\hline Brwilno & 642 & reolimnic & 29.9 & 84.0 \\
\hline Wloclawek & 674 & limnic & 22.5 & 188.2 \\
\hline
\end{tabular}

zone formation below the Wloclawek Dam. This phenomenon is related to the sediments deficiency, which has been accumulated in the reservoir. In literature, it functions under the name "hungry water" [Kondolf, 1997]. The values of turbidity and concentrations of total suspension reach the lowest values in the entire tested Vistula River longitudinal profile (Figure 2).

Below the dam, intense bed erosion is observed, estimated at 0.7-1.1 million $\mathrm{t} \cdot \mathrm{year}^{-1}$. Propagation rate of the erosion zone moving down the river is estimated at $1.1 \mathrm{~km} \cdot \mathrm{year}^{-1} \mathrm{un}-$ til the erosive zone reaches the section regulated in the 19th century $(718 \mathrm{~km})$ [Babiński, 1992], then at $2.2 \mathrm{~km} \cdot$ year $^{-1}$ [Habel et al., 2016]. This results in lifting bedload material (including gravel and sand), causing erosion thresholds. Currently (2016) the forehead of the erosion zone is locat-

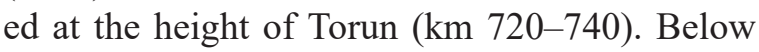
the erosion zone, an accumulation zone has been formed, which is characterized by shallowing the river channel on average by about $0.2 \mathrm{~m} \cdot$ year $^{-1}$. It is characterized by an increased concentration of suspended sediments in the Vistula River. The transport of suspended (Figure 2) and bedload sediments occurs again, however, it does not reach its original level till the estuary to Baltic Sea [Babiński, 1992].

According to long-term forecasts, if the current rate of movement, set at $2.2 \mathrm{~km} \cdot \mathrm{year}^{-1}$, is maintained, the zone of indirect impact of the Wloclawek Reservoir will reach the Baltic Sea coastal zone around 2100 [Habel et al., 2016]. Artificial reservoirs contribute to reducing of the supply of sediments to the world's ocean, contributing to the erosion of delta areas on a global scale [Meade, Moody, 2010; Giosan et al., 2014].

The dynamics of suspended sediments transport in the longitudinal profile of the Vistula River was also determined in terms of the size of the suspended grains. Research of the volumetric distribution of suspended load concentration and particle grain size of silt showed renewal capability of river load below Wloclawek Reservoir. A drop in the value of the indicators under research is observed below the dam (Figure 3). It results from the domination of the process of lifting of the suspended material downstream. Then, the renewal of transport of suspended sediments is observed. Grain size lager than $63 \mu \mathrm{m}$ at the stations: Torun $(73 \mu \mathrm{m})$ and Bydgoszcz - Fordon $(83 \mu \mathrm{m})$ shows a growing trend (Figure 3 ). The values of

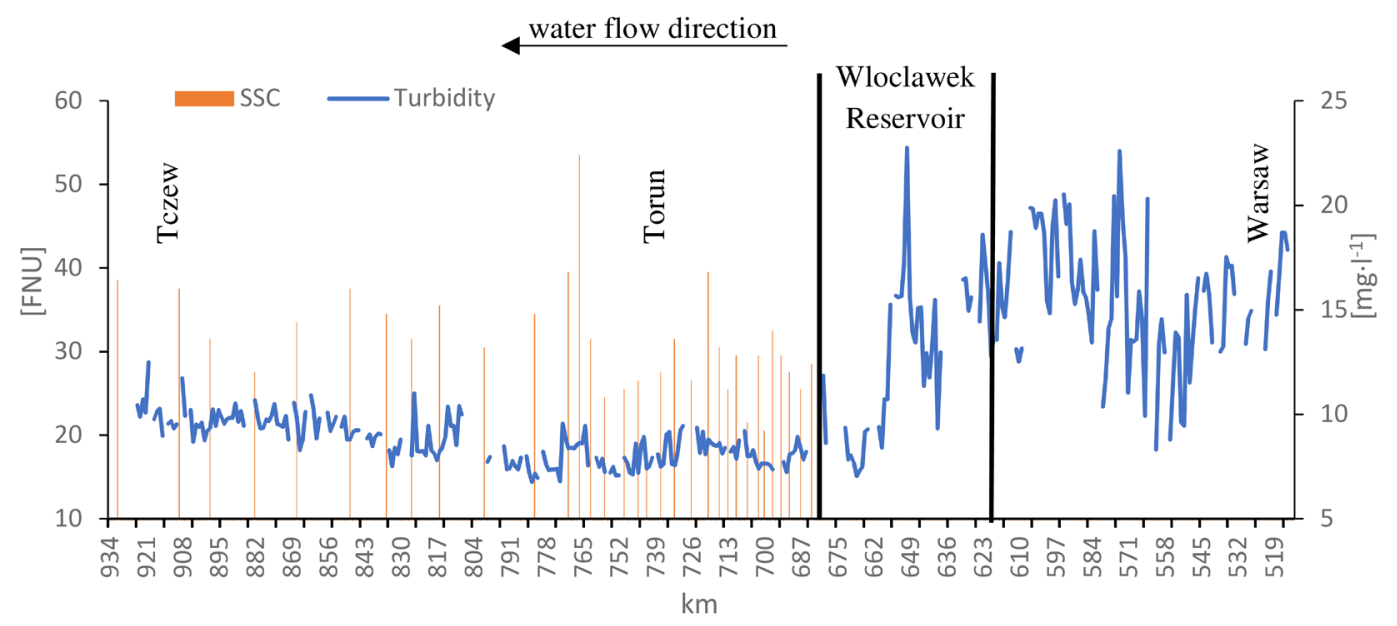

Figure 2. Turbidity [in FNU] and suspended sediments concentration [in $\mathrm{mg} \cdot \mathrm{l}^{-1}$ ] in the longitudinal profile of Vistula River 
the analyzed indicators noticeably increase at the border of erosion and accumulation zones.

\section{THE COURSE OF TURBIDITY IN DIFFERENT HYDROLOGICAL CONDITIONS}

By means of curvilinear functions, a relationship was found between the concentration of the suspended sediments in the river channel and the discharge [Webb, Walling, 1984; Ciupa, 2009]. This was confirmed by the studies on the variability of the suspended sediments concentration in the Wloclawek Reservoir made by Achrem and Gierszewski [2007] in the years 1982-2002 showing the correlation with the discharge, phytoplankton growth and locally - supply as a result of coastal erosion. However, due to the fact that the hydrological factor is dominant, the frequency of high discharges (including floods) is decisive when it comes to the dynamics of the suspended sediments transport.

During the flood in 2014, research was carried out on the concentration of total suspended material in the Vistula River waters at two measurements stations above (Plock) and below (Torun) of the Wloclawek Reservoir (Figure 4). They show significant dynamics of the Vistula River waters' turbidity at the period of a flood. Higher concentrations are recorded at the station above the reservoir, which indicates the accumulation of suspended sediments in the reservoir. There was a hysteresis effect, occurring between the discharge of water in the channel and the concentration of transported material related to the supply and/or depletion of material for transportation in the river channel [Kostrzewski et al., 1994]. The maximum concentration of suspended material precedes the maximum stage (discharge) of water in the river channel. On this basis, it can be concluded that the normal loop system corresponds to the supply of indigenous material from the river channel and the Vistula floodplain.

Differentiation in water turbidity in the Vistula River channel is also visible in the case of water stage / discharge not counted as high. The differences result mainly from the morphometric diversity of the river channel (deeps / shallows), supplying from sections actively undercut as a result of bank erosion. A double measurement series (May and July 2015) were conducted in the Vistula border section between the erosive and accumulation zone (near Torun) in the case of different hydrological conditions. Modelling of the spatial distribution of the water turbidity of the

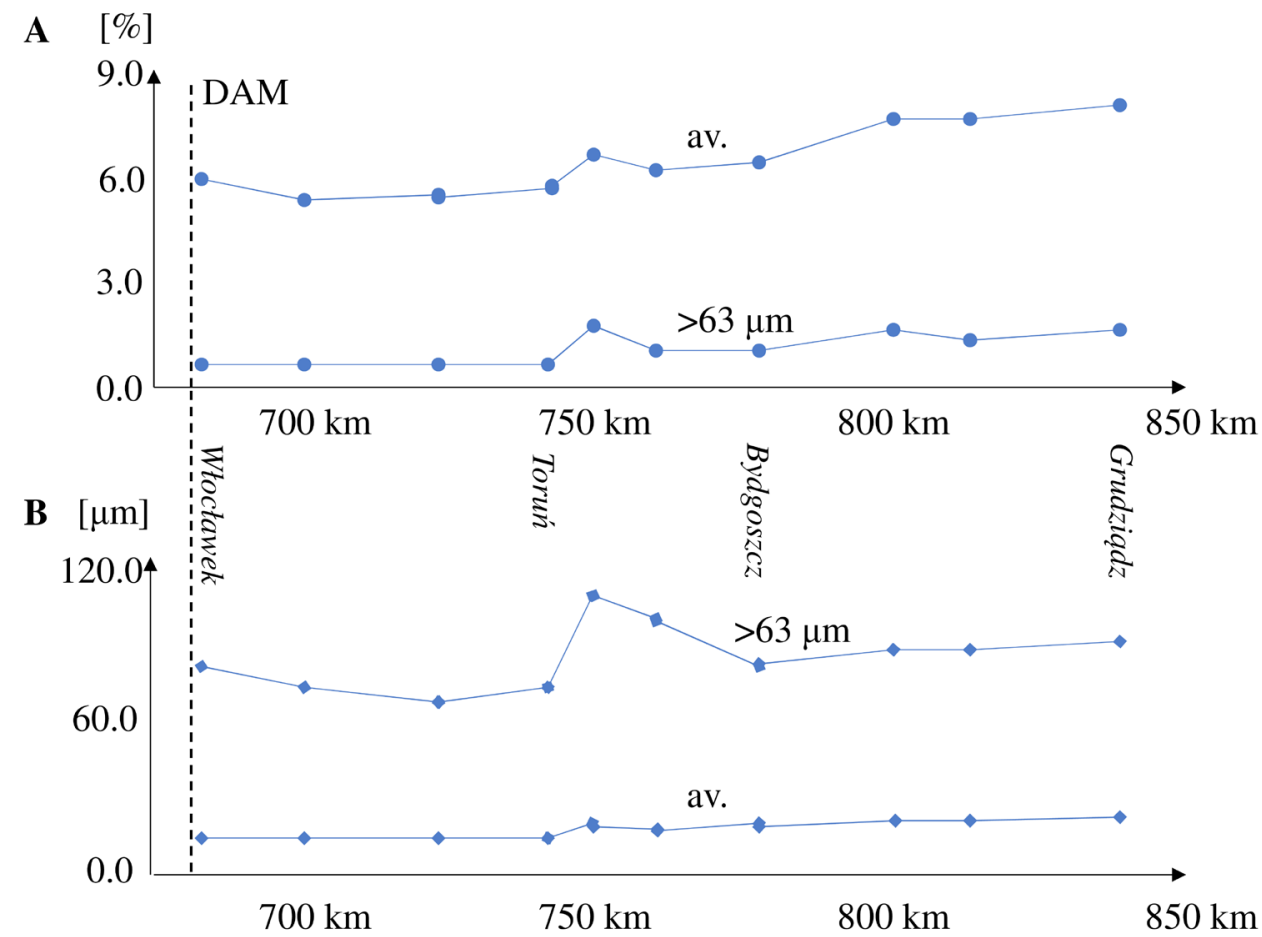

Figure 3. Suspended sediment distribution along the lower Vistula river below the Wloclawek Reservoir in 2014: A - volumetric concentration of suspended silt as average value measured in cross section; B - grain size of silt, average value measured in cross section. 


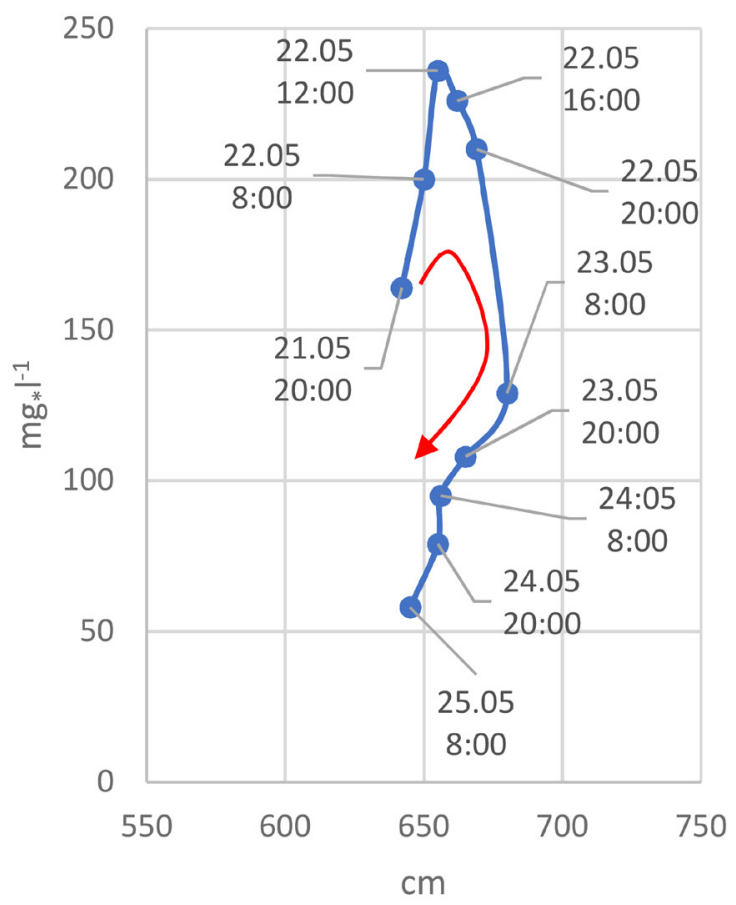

PLOCK

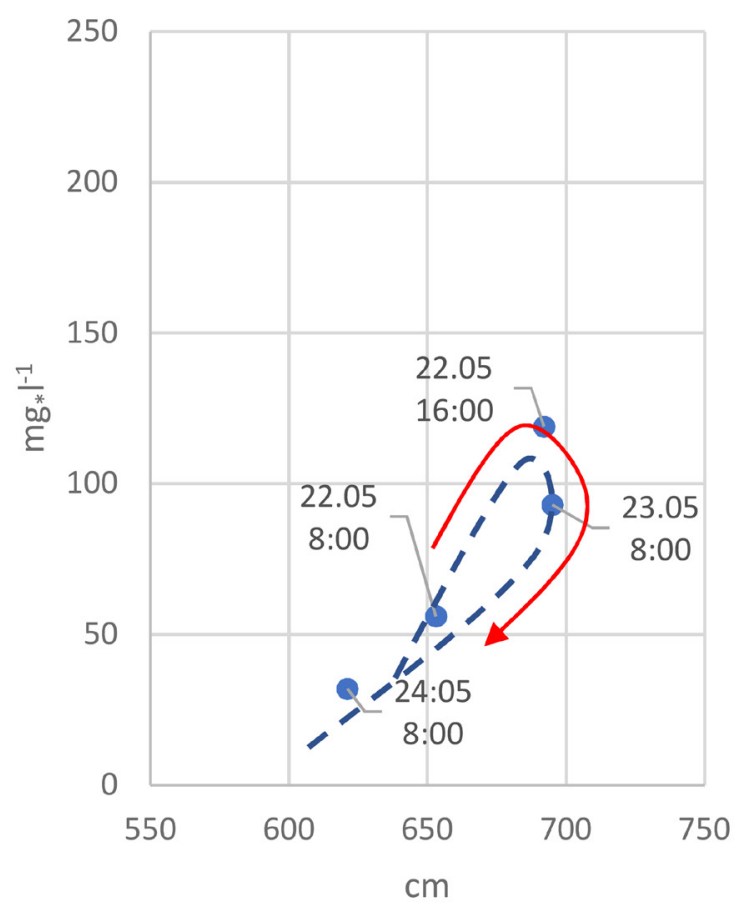

TORUN

Figure 4. The comparison of the concentration of total suspended sediments at two contiguous measuring stations in the longitudinal profile of Vistula River in the period 21.05 - 25.05.2015
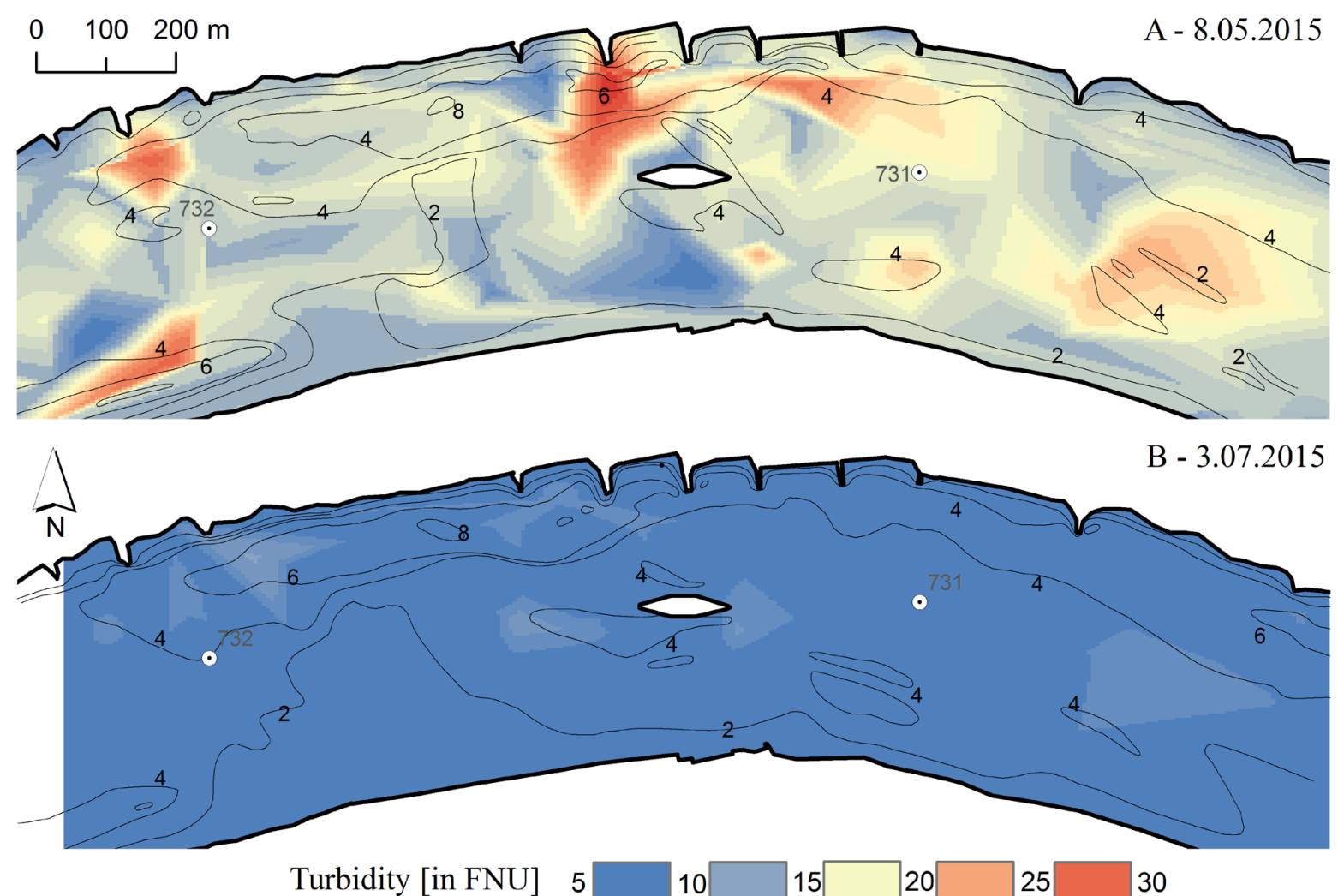

Figure 5. Modelling of water turbidity in the Vistula River channel near Torun in the case of various hydrological conditions: water discharge $\mathrm{A}-673 \mathrm{~m}^{3} \cdot \mathrm{s}^{-1} ; \mathrm{B}-350 \mathrm{~m}^{3} \cdot \mathrm{s}^{-1}$. 
Vistula River channel shows its strong internal differentiation (Figure 5). At a discharge of 670 $\mathrm{m}^{3} \cdot \mathrm{s}^{-1}$ (Figure 5A), the highest value of turbidity occurs at the right bank - eroded. They amount locally over 30.0 FNU. The lowest values of water turbidity are characteristic for the areas of the channel with a small depth (underwater sandbars), where the value of turbidity is about 5 FNU. In the case of a lower discharge in the Vistula (350 $\mathrm{m}^{3} \cdot \mathrm{s}^{-1}$ ), smaller values of turbidity are clearly visible in modelling (Figure 5B). They range from 5 to $10 \mathrm{FNU}$. However, the spatial distribution of values is influenced by the same factors as in the case of larger discharge.

\section{CONCLUSIONS}

Based on the research carried out on the dynamics of suspended sediments (to a lesser extent, bedload material) in the Lower Vistula River region, the following conclusions can be made:

1. Wloclawek Reservoir captures a large part of the suspended sediments (42-50\%) and 100\% of the bedload sediments, significantly determining the dynamics of fluvial transport in the longitudinal profile of the Vistula River.

2. This results in the creation of the zone of intense material erosion below the dam (currently reaching up to $\mathrm{km} 720-740$ ) which then goes into the zone of increased sediments accumulation.

3. The capturing of suspended sediments load by the Wloclawek Reservoir (functioning in the present system as a single dam) directly determines the course of fluvial processes on the section of the whole Lower Vistula River (from $\mathrm{km} 675$ to the estuary) and indirectly in the coastal zone of the Baltic Sea.

4. The commission of new dam may contribute to the stabilization of fluvial processes in the section of the impact of the cascade of reservoirs - Wloclawek (existing) and Siarzewo (planned).

\section{Acknowledgements}

The research was funded by Polish Ministry of Science (Maintenance of the Research Potential of the Department of Physical Edu., Health and Tourism at Kazimierz Wielki University; no. BS/2017/N2).

\section{REFERENCES}

1. Achrem E., Gierszewski P. 2007. Zbiornik Włocławski (in Polish). Biblioteka Monitoringu Środowiska, Bydgoszcz.

2. Agrawal Y.C., Pottsmith H.C. 2000. Instruments for particle size and settling velocity observations in sediment transport. Mar. Geol., 168, 89-114.

3. Babiński Z. 1992. Hydromorphological consequences of regulating the lower Vistula, Poland. Regulated Rivers: Research \& Management, 7(4), 337-348.

4. Babiński Z. 2002. Wpływ zapór na procesy korytowe rzek aluwialnych ze szczególnym uwzględnieniem Zbiornika Włocławskiego (in Polish). Wyd. Akademii Bydgoskiej im. Kazimierza Wielkiego, Bydgoszcz.

5. Babiński Z. 2005. The relationship between suspended and bed load transport in river channels. Proc. International Symposium held at the 7th Scientific Assembly of the International Association of Hydrological Sciences, 182-188.

6. Brański J. 1990. Instrukcja wykonywania i opracowania pomiarów rumowiska unoszonego (in Polish). Instytut Meteorologii i Gospodarki Wodnej, Warszawa.

7. Byczkowski A., Żelazo J. 1992. Zmiany reżimu górnej Narwi w wyniku prac melioracyjnych (in Polish). Gospodarka Wodna, 1, 22-25.

8. Ciupa T. 2009. Wpływ zagospodarowania terenu na odpływ i transport fluwialny w małych zlewniach na przykładzie Sufragańca i Silnicy (in Polish). Wyd. Uniwersytetu Jana Kochanowskiego, Kielce.

9. Directive 2000/60/EC of the European Parliament and of the Council establishing a framework for the Community action in the field of water policy (dostęp: http://eur-lex.europa.eu/legal-content/EN/ TXT/PDF/?uri=CELEX:32000L0060\&rid=1).

10. Felix D., Albayrak I., Abgottspon A., Boes R.M. 2016. Real-time measurements of suspended sediment concentration and particle size using five techniques. Proc. IOP: Earth and Environmental Science, 1057-1066.

11. Gierszewski P. 2007. Warunki transportu zawiesiny w Zbiorniku Włocławskim w świetle analizy jej składu i tekstury (in Polish). Nauka Przyroda Technologie, 2, 1-18.

12. Gierszewski P., Glazik R., Kuciński J. 2005. Multiannual variability of the concentration of suspended matter in the Włocławek reservoir. Limnological Review, 5, 81-91.

13. Giosan L., Syvitski J.P.M., Constantinescu S., Day J. 2014. Protect the world's deltas. Nature, 516, 31-33.

14. Habel M. 2013. Dynamics of the Vistula River channel deformations downstream of Włocławek Reservoir. Kazimierz Wielki University Press, Bydgoszcz. 
15. Habel M., Babiński Z., Szatten D., Chalov S., Zakhar R., Maerker M. 2016. Clastic sediment transport renewal below Włocławek Reservoir. In: Chaberek-Karwacka G., Malinowska M. (eds.): Geography in the Face of Modern World Challenges. Wyd. LIBRON, Kraków.

16. Habel M., Babiński Z., Szatten D. 2017. A comparison of research approaches in estimation of volume changes of a bed load transport along a river course on the example of a large lowland river. Proc. of the International Conference of Computational Methods in Sciences and Engineering, 170009(1-4).

17. Hu B., Yang Z., Wang H., Sun X., Bi N., Li G. 2009. Sedimentation in the Three Gorges Dam and the future trend of Changjiang (Yangtze River) sediment flux to the sea. Hydrol. Earth Syst. Sci., 13, 2253-2264

18. Knighton D. 1998. Fluvial forms and processes. A new perspective. Co-published John Wiley and Sons Inc., New York.

19. Kondolf G. 1997. Hungry water: Effects of Dams and Gravel Mining on River Channels. Environ. Manage, 21(4), 533-551.

20. Kondolf G.M. Gao, Y., Annandale G., Morris G., Jiang E., Zhang J., Cao Y., Carling P., Fu K., Guo Q., Hotchkiss R., Peteuil Ch., Sumi T., Wang H.W., Wang Z., Wei Z., Wu, B., Wu, C., Yang C. 2014. Sustainable sediment management in reservoirs and regulated rivers: Experiences from five continents. Earth's Future, 2, 1-25.

21. Kondracki J. 2002. Geografia regionalna Polski (in Polish). Wyd. Nauk. PWN, Warszawa.

22. Kostrzewski A., Mazurek M., Zwoliński Z. 1994. Dynamika transportu fluwialnego górnej Parsęty jako odbicie funkcjonowania systemu zlewni (in Polish). Stowarzyszenie Geomorfologów Polskich, Poznań.

23. Łajczak A. 1999. Współczesny transport i sedymentacja materiału unoszonego w Wiśle i jej dopływach (in Polish). Oficyna Wydawnicza Politechniki Warszawskiej, Warszawa.

24. Magnuszewski A., Moran S., Yu G. 2010. Modelling lowland reservoir sedimentation conditions and the potential environmental consequences of dam removal: Wloclawek Reservoir, Vistula River, Poland. Proc. IAHS, 345-352.

25. Mapa podziału hydrograficznego Polski. 2007. Zakład Hydrografii i Morfologii Koryt Rzecznych. IMGW, Warszawa.
26. Meade R.H., Moody J.A. 2010. Causes for the decline of suspended - sediment discharge in the Mississippi River system, 1940-2007. Hydrol. Process., 24, 35-49.

27. Nilsson C., Reidy C.A., Dynesius M., Revenga C. 2005. Fragmentation and flow regulation of the world's large river systems. Science, 308, 405-408.

28. Rocznik statystyczny Rzeczpospolitej Polskiej. 2017. GUS, Warszawa.

29. Shotbolt L.A., Thomas A.D., Hutchinson S.M. 2005. The use of reservoir sediments as environmental archives of catchment inputs and atmospheric pollution. Progress in Physical Geography, 29(3), 337-361.

30. Slaets J.I.F., Schmitter P., Hilger T., Lamers M., Piepho H., Vien T.D., Cadisch G. 2014. A turbidity-based method to continuously monitor sediment, carbon and nitrogen flows in mountainous watersheds. Journal of Hydrology, 513, 45-57.

31. Syvitski J.P.M., Kettner A.J., Overeem I., Hutton E.W., Hannon M.T., Brakenridge G.R., Day J., Vörösmarty C.J., Saito Y., Giosan L., Nicholls R.J. 2009. Sinking deltas due to human activities. Nature Geoscience, 2(10), 681-686.

32. Syvitski J.P.M., Kettner A.J. 2011. Sediment flux and the Anthropocene. Phil. Trans. R. Soc., 957-975.

33. Turowski J.M., Rickenmann D., Dadson S.J. 2010. The partitioning of the total sediment load of a river into suspended load and bedload: A review of empirical data. Sedimentology, 57, 1126-1146.

34. Van Rijn L. 1984. Sediment Transport. Part III: Bed forms and alluvial roughness. Journal of Hydraulic Engineering, 110(12), 1733-1754.

35. Vörösmarty C.J., Meybeck M., Fekete B., Sharma K., Green P., Syvitski J.P.M. 2003. Anthropogenic sediment retention: major global impact from registered river impoundments. Global and Planetary Change, 39(1-2), 169-190.

36. Walling D.E., Fang D. 2003. Recent trends in the suspended sediment loads of the world's rivers. Global Planet. Change, 39, 111-126.

37. Webb B.W., Walling D.E. 1984. Magnitude and frequency characteristics of suspended sediment transport in Devon rivers. In: Burt T.P., Walling D.E. (eds.): Catchment Experiments in Fluvial Geomorphology. Geo Books, 399-415.

38. Wren D., Barkdoll B., Kuhnle R., Derrow R. 2000. Field Techniques for Suspended-Sediment Measurement. Journal of Hydraul. Eng., 126(2), 97-104. 